\title{
Spray volumes and fungicide rates on Asian soybean rust control
}

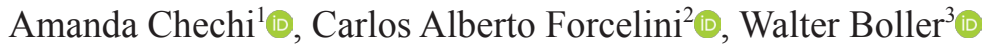

\begin{abstract}
${ }^{1}$ Agronomy Doctoral Student at PPGAgro/UPF. E-mail: amandachechi@hotmail.com. University of Passo Fundo, BR 285, São José, Zip Code 99052-900, Passo Fundo/RS, Brazil. ²Professor of FAMV/UPF. E-mail: forcelini@upf.br. University of Passo Fundo, BR 285, São José, Zip Code 99052-900, Passo Fundo/ RS, Brazil. 3Professor of FAMV/UPF. E-mail: boller@upf.br. University of Passo Fundo, BR 285, São José, Zip Code 99052-900, Passo Fundo/ RS, Brazil.
\end{abstract}

Autor para correspondência: Walter Boller (boller@upf.br)

Data de chegada: 26/07/2017. Aceito para publicação em: 30/01/2019.

$10.1590 / 0100-5405 / 183205$

\section{ABSTRACT}

Chechi, A.; Forcelini, C.A.; Boller, W. Spray volumes and fungicide rates on Asian soybean rust control. Summa Phytopathologica, v.45, n.3, p.255-260, 2019.

The aim of this study was to assess the effect of different spray volumes and fungicide rates on Asian soybean rust control. Experiments were conducted in the field and in the laboratory during 2014 and 2016. We varied the fungicide rates $\left(45+52.5,60+70\right.$ and $75+87.5 \mathrm{~g}$ a.i. ha $^{-1}$ for the mixture trifloxystrobin + prothioconazole, and $45+22.5,60+30$ and $75+37.5 \mathrm{~g}$ a.i. ha $^{-1}$ for azoxystrobin + benzovindiflupyr) and the spray volume (100, 150 and $200 \mathrm{~L} \mathrm{ha}^{-1}$ ) for application on soybean plants in the field. Another experiment was conducted in the laboratory, using the recommended rates of the fungicides trifloxystrobin
+ prothioconazole $\left(60+70 \mathrm{~g}\right.$ a.i. $\left.\mathrm{ha}^{-1}\right)$ and azoxystrobin + benzovindiflupyr $(60$ $+30 \mathrm{~g}$ a.i. $\left.\mathrm{ha}^{-1}\right)$. The spray volume of $200 \mathrm{~L} \mathrm{ha}^{-1}$ resulted in the best disease control only for the third out of three applications carried out in the field (control between $68.4 \%$ and $70.1 \%$ ). However, there was no statistical difference in grain yield for all tested spray volumes when we used the recommended fungicide rates $\left(3422,3526\right.$ and $\left.3601 \mathrm{~kg} \mathrm{ha}^{-1}\right)$ or higher rates $(3529,3586$ and $3550 \mathrm{~kg}$ $\left.\mathrm{ha}^{-1}\right)$. The decrease in the fungicide rate directly implied reduced rust control for both experiments ( 20 to $39 \%$ in the field and up to $71.4 \%$ in the laboratory).

Keywords: chemical control, Glycine max, Phakopsora pachyrhizi, application technology.

\section{RESUMO}

Chechi, A.; Forcelini, C.A.; Boller, W. Volumes de calda e doses de fungicidas no controle da ferrugem-asiática da soja. Summa Phytopathologica, v.45, n.3, p.255-260, 2019.

O objetivo deste trabalho foi verificar o efeito de diferentes volumes de calda e de doses de fungicidas no controle da ferrugem-asiática da soja (FAS). Os ensaios foram conduzidos no campo e em laboratório, durante 2014 e 2016. Variou-se a dose $\left(45+52,5,60+70\right.$ e $75+87,5$ g i.a. ha ${ }^{-1}$ para a mistura de trifloxistrobina + protioconazol e $45+22,5,60+30$ and 75 $+37,5$ g i.a. $\mathrm{ha}^{-1}$ de azoxistrobina + benzovindiflupir) e o volume de calda $\left(100,150\right.$ e $\left.200 \mathrm{~L} \mathrm{ha}^{-1}\right)$ na aplicação de fungicidas sobre plantas de soja no campo. Também foi realizado ensaio em laboratório com uso das doses recomendadas dos fungicidas trifloxistrobina + protioconazol $(60+70 \mathrm{~g}$ i.a. ha $\left.{ }^{-1}\right)$ e azoxistrobina + benzovindiflupir $\left(60+30 \mathrm{~g}\right.$ i.a ha $\left.\mathrm{a}^{-1}\right)$. O volume de calda de $200 \mathrm{~L} \mathrm{ha}^{-1}$ resultou no melhor controle da doença somente na terceira, dentre as três aplicações realizadas no campo (controle entre $68,4 \%$ e $70,1 \%$ ). No entanto, não houve diferença estatística no rendimento de grãos para todos os volumes de calda testados, quando utilizadas as doses recomendadas $\left(3422,3526\right.$ and $\left.3601 \mathrm{~kg} \mathrm{ha}^{-1}\right)$ e as doses superiores a ela $\left(3529,3586\right.$ and $\left.3550 \mathrm{~kg} \mathrm{ha}^{-1}\right)$. A redução na dose de fungicida resultou diretamente na redução do controle da FAS para ambos os ensaios (20 a $39 \%$ no campo e até $71,4 \%$ em laboratório).

Palavras-chave: controle químico, Glycine max, Phakopsora pachyrhizi, tecnologia de aplicação.

Asian soybean rust (ASR), caused by Phakopsora pachyrhizi Syd. \& Syd., is considered one of the most destructive diseases causing damage to soybean plants [Glycine max (L.) Merr] and other members of the Fabaceae family (19). Presenting sporewind dissemination, this pathogen is found in almost all soybean producing regions in Brazil, causing up to $75 \%$ yield loss (3).

According to Santos et al. (22), ASR control is mostly based on fungicide applications. With the aim of reducing the costs of chemical control, studies on reduced spray volumes for fungicide applications have been developed (23). The same occurs for fungicide rates. Azevedo (5) reported that fungicide spraying requires better coverage of the biological target than other classes of agricultural pesticides.

To reduce costs, producers often adopt reduced fungicide rates and spray volumes, which leads to evidently lower treatment efficacy. Thus, changing the recommended fungicide rates may affect the disease control effectiveness; furthermore, problems such as reduced fungicide efficacy can be caused by decreased fungal sensitivity. Reduced or no fungicide efficacy can be monitored by different methods, the choice of which will depend on the target pathogen and on the chemical properties of the fungicide. In vivo tests generally include the use of plant parts, especially leaves, leaf discs or segments deposited on a culture medium containing the fungicide $(6,7,14)$.

In the present study, we hypothesized that a reduction in both the fungicide rate and the spray volume decreases ASR control and soybean yield. The objective of this study was to verify if different fungicide rates and spray volumes affect ASR control. 


\section{MATERIAL AND METHODS}

Experiments were conducted in an experimental field, in a greenhouse and in a growth chamber at University of Passo Fundo, Passo Fundo City - Rio Grande do Sul State, Brazil. Latitude, longitude and altitude were $28^{\circ} 15$ ' $\mathrm{S}, 52^{\circ} 24^{\prime}$ ' $\mathrm{W}$ and $687 \mathrm{~m}$.a.s.l, respectively.

The field trial was implemented in the 2014/2015 growing season, and the employed soybean cultivar was NS 5445 IPRO, which has indeterminate growth habit. The experiment was conducted in randomized block design, using five replicates. The plots measured $2.25 \mathrm{~m} \times 5.0 \mathrm{~m}$ and were composed of five cultivated rows.

The soil is classified as Dystrophic Dark Red Latosol. Accumulated rainfall during December 2014 and January, February and March 2015 was $696.8 \mathrm{~mm}, 73.2 \mathrm{~mm}$ above the normal historic for the period. However, almost half of the precipitation was observed in January $(333.5 \mathrm{~mm})$. The mean temperatures for this period were similar to the normal historic (around $21^{\circ} \mathrm{C}$ ), and minimum $\left(17^{\circ} \mathrm{C}\right)$ and maximum $\left(28^{\circ} \mathrm{C}\right)$ temperatures were slightly above and below it, respectively $(12,13)$.

Fourteen seeds per meter, spaced $0.45 \mathrm{~m}$ between rows, were sown under no-tillage system, in the end of November, using wheat crop residues. Weed and pest management was carried out according to the official technical recommendation for the crop (18).

Fungicides were applied three times. The first application was carried out before the pathogen was detected in the area, at 50 days after sowing (DAS), using trifloxystrobin + prothioconazole $(60+70 \mathrm{~g}$ a.i. $\left.\mathrm{ha}^{-1}\right)$ and vegetable oil composed of methyl ester of soybean oil (360 g a.i. ha ${ }^{-1}$, while the second and the third applications were done at 67 and 88 DAS, respectively, using azoxystrobin + benzovindiflupyr $(60+30$ $\mathrm{g}$ a.i. ha $\left.\mathrm{h}^{-1}\right)$ and mineral oil $\left(256.8 \mathrm{~g}\right.$ a.i. $\left.\mathrm{ha}^{-1}\right)$. Three fungicide volumes were sprayed $\left(100,150\right.$ and $\left.200 \mathrm{~L} \mathrm{ha}^{-1}\right)$, as well as three rates $(45+$ $52.5,60+70$ and $75+87.5 \mathrm{~g}^{2}$ a.i. $\mathrm{ha}^{-1}$ for the mixture trifloxystrobin + prothioconazole, and $45+22.5,60+30$ and $75+37.5 \mathrm{~g}$ a.i. ha ${ }^{-1}$ for azoxystrobin + benzovindiflupyr), characterizing a $3 \times 3$ factorial design and one control, which did not receive fungicide application (Table 1).

The pressurized $\mathrm{CO}_{2}$ backpack sprayer employed for the application of volumes of 100 and $150 \mathrm{~L} \mathrm{ha}^{-1}$ had a four-nozzle bar spaced $0.45 \mathrm{~m}$ and single plane jet tips, Teejet ${ }^{\mathbb{R}}$ XR 110015 series, operating at 2.0 bar $(200 \mathrm{kPa})$ pressure; for the application of $200 \mathrm{~L} \mathrm{ha}^{-1}$, the pressure was 3.0 bar $(300 \mathrm{kPa})$, Teejet ${ }^{\circledR}$ XR 11002 series, and both tips produced fine-grade drops (106-235 $\mu \mathrm{m})$.

The disease severity was assessed fortnightly from the date of the first fungicide application. The disease intensity was evaluated by using the diagrammatic scale proposed by Godoy et al. (15), collecting all leaves in the main stem of three plants per plot. The leaf area index was obtained for the same leaves, including branches, using a LI-3100C ${ }^{\circledR}$ area meter. The harvested area in each plot was $6.75 \mathrm{~m}^{2}$ (three central rows). Grain moisture (\%), yield $\left(\mathrm{kg} \mathrm{ha}^{-1}\right)$ and thousand grain mass $(\mathrm{g})$ were determined, adjusting moisture to $13 \%$.

The second experiment was conducted in the laboratory, in a greenhouse and in a growth chamber. Soybean leaflets were obtained from plants grown in fifty $2000-\mathrm{mL}$ pots filled with substrate and sowed with seeds of NS 5445 IPRO soybean cultivar in the greenhouse. Forty days after sowing, the central leaflets of the seventh leaf of each plant were collected.

Experimental units were composed of germination boxes Gerbox ${ }^{\circledR}$ (gerbox), in which wet chambers were prepared. These wet chambers contained a gerbox-sized polyethylene foam unit $\left(121 \mathrm{~cm}^{2}\right)$ and two filter paper sheets of the same size which were moistened with distilled water.
Table 1. Spray volumes $\left(\mathrm{L} \mathrm{ha}^{-1}\right)$ and rates $\left(\mathrm{g}\right.$ a.i. ha $\left.{ }^{-1}\right)$ of fungicides used in field applications, as well as fungicide commercial rate percentages and respective amounts of active ingredient per hectare used in the laboratory trial. Passo Fundo/RS, 2016

\begin{tabular}{|c|c|c|c|c|}
\hline \multicolumn{5}{|c|}{ Field Treatments } \\
\hline Treatment & $\begin{array}{c}\text { Spray } \\
\text { volume } \\
\left(\mathrm{L} \mathrm{ha}^{-1}\right)\end{array}$ & $\begin{array}{c}\text { Fungicide } \\
\text { comercial } \\
\text { rate } \\
(\%) \\
\end{array}$ & $\begin{array}{c}\text { Trifloxystrobin } \\
\qquad \\
+ \\
\text { prothioconazole } \\
\quad\left(\text { g a.i. }^{-1} \text { ha }^{-1}\right) \\
\end{array}$ & $\begin{array}{c}\text { Azoxystrobin + } \\
\text { benzovindiflupyr } \\
\text { e }\left(\mathrm{g} \text { a.i. } \text { ha }^{-1}\right)\end{array}$ \\
\hline 1 & - & - & - & - \\
\hline 2 & 100 & 100 & $60+70$ & $60+30$ \\
\hline 3 & 100 & 125 & $75+87.5$ & $75+37.5$ \\
\hline 4 & 100 & 75 & $45+52.5$ & $45+22.5$ \\
\hline 5 & 150 & 100 & $60+70$ & $60+30$ \\
\hline 6 & 150 & 125 & $75+87.5$ & $75+37.5$ \\
\hline 7 & 150 & 75 & $45+52.5$ & $45+22.5$ \\
\hline 8 & 200 & 100 & $60+70$ & $60+30$ \\
\hline 9 & 200 & 125 & $75+87.5$ & $75+37.5$ \\
\hline 10 & 200 & 75 & $45+52.5$ & $45+22.5$ \\
\hline \multicolumn{5}{|c|}{ Laboratory Treatments } \\
\hline \multicolumn{2}{|c|}{$\begin{array}{l}\text { Treatment (\% } \\
\text { recommended } \\
\text { fungicide rate) }\end{array}$} & \multicolumn{2}{|c|}{$\begin{array}{c}\text { Trifloxystrobin + } \\
\text { prothioconazole } \\
\left(\mathrm{g} \text { a.i. } \text { ha }^{-1}\right) \\
\end{array}$} & $\begin{array}{c}\text { Azoxystrobin + } \\
\text { genzovindiflupyr } \\
\left(\text { g a.i. } \text { ha }^{-1}\right) \\
\end{array}$ \\
\hline \multicolumn{2}{|l|}{0} & \multicolumn{2}{|l|}{-} & - \\
\hline \multicolumn{2}{|l|}{10} & \multicolumn{2}{|l|}{$6+7$} & $6+3$ \\
\hline \multicolumn{2}{|l|}{20} & \multicolumn{2}{|l|}{$12+14$} & $12+6$ \\
\hline \multicolumn{2}{|l|}{30} & \multicolumn{2}{|l|}{$18+21$} & $18+9$ \\
\hline \multicolumn{2}{|l|}{40} & \multicolumn{2}{|l|}{$24+28$} & $24+12$ \\
\hline \multicolumn{2}{|l|}{50} & \multicolumn{2}{|l|}{$30+35$} & $30+15$ \\
\hline \multicolumn{2}{|l|}{60} & \multicolumn{2}{|l|}{$36+42$} & $36+18$ \\
\hline \multicolumn{2}{|l|}{70} & \multicolumn{2}{|l|}{$42+49$} & $42+21$ \\
\hline \multicolumn{2}{|l|}{80} & \multicolumn{2}{|l|}{$48+56$} & $48+24$ \\
\hline \multicolumn{2}{|l|}{90} & \multicolumn{2}{|l|}{$54+63$} & $54+27$ \\
\hline \multicolumn{2}{|l|}{100} & \multicolumn{2}{|l|}{$60+70$} & $60+30$ \\
\hline
\end{tabular}

Treatments consisted of different rates of two fungicide mixtures, one of them was composed of trifloxystrobin + prothioconazole (commercial rate: $60+70 \mathrm{~g}$ a.i. $\mathrm{ha}^{-1}$ ) and the other one was composed of azoxystrobin + benzovindiflupyr $\left(60+30 \mathrm{~g}\right.$ a.i. ha $\left.{ }^{-1}\right)$ (Table 1$)$. Suspensions were prepared in 500-mL plastic cups containing 300 $\mathrm{mL}$ distilled water, without addition of adjuvants. Concentrations were prepared for $100 \mathrm{~L} \mathrm{ha}^{-1}$ spray volume. Experimental design was in completely randomized way and six replicates. The used methodology was adapted from the detached leaf test of Scherb \& Mehl (16). Six leaflets were used for each fungicide rate. They were immersed in their respective fungicide solutions for five seconds for perfect coverage. Then, each leaflet was placed in a gerbox and was allowed to dry with 
the adaxial side facing up, in the dark, at room temperature. A piece of cotton saturated with distilled water was added to the petioles of the leaflets.

Leaflets were inoculated with a $P$. pachyrhizi spore suspension $\left(5 \times 10^{4}\right.$ spores $\left.\mathrm{mL}^{-1}\right)$ twenty-four hours after fungicide application. The inoculum was collected from soybean leaflets in the field. Distilled water $(200 \mathrm{~mL})$ was added in a $500-\mathrm{mL}$ Erlenmeyer plus one drop of Tween ${ }^{\circledR}$ spreader and the soybean leaflets with ASR. After shaking, the spore suspension and the leaflets were separated. Spore concentration was estimated in a hemocytometer. Using a $500-\mathrm{mL}$ sprayer, the suspension was applied to leaflets. For spore germination, the gerboxes were kept in the dark for 24 hours, at $23^{\circ} \mathrm{C}\left(+/-2^{\circ} \mathrm{C}\right)$.

After this period, the boxes were placed in a growth chamber at 12-hour photoperiod and $23^{\circ} \mathrm{C}\left(+/-2^{\circ} \mathrm{C}\right)$. Every two days, water was added to maintain the humidity. After 22 days of incubation, the pustules on each leaflet were counted in an area of $2.0 \mathrm{~cm}^{2}$ per leaflet $\left(1.0 \mathrm{~cm}^{2}\right.$ each side of the leaflets in the abaxial face) under a stereomicroscope. The percentage of disease control was obtained by using the formula $\mathrm{PC}(\%)=(\mathrm{T}-\mathrm{t}) * 100 / \mathrm{T}(1)$, where ' $\mathrm{T}$ ' is the number of pustules for the unsprayed control and ' $\mathrm{t}$ ' is the number of pustules for the treatment. The experiments with both fungicide mixtures were repeated twice and their average was calculated by verifying the homogeneity of variance. The data underwent analysis of variance, Scott-Knott test and simple linear regression.

\section{RESULTS AND DISCUSSION}

Field experiment. Both the fungicide rate and the spray volume influenced rust control efficacy (Table 2). There was no interaction between factors.

Mean disease severity at 100 DAS was $52 \%$ for untreated plants. The low severity found at 60 and 80 DAS influenced the statistical non-differentiation for all the volumes with recommended and increased rates, which were the best treatments for the first and second applications. At $100 \mathrm{DAS}$, the best performance was obtained for treatments with $200 \mathrm{~L} \mathrm{ha}^{-1}$ spray volume and the recommended rates of trifloxystrobin + prothioconazole $\left(60+70 \mathrm{~g}\right.$ a.i. $\left.\mathrm{ha}^{-1}\right)$ and azoxystrobin + benzovindiflupyr $\left(60+30 \mathrm{~g}\right.$ a.i. ha $\left.{ }^{-1}\right)$, as well as increased rates $(75$ $+87.5 \mathrm{~g}$ a.i. ha ${ }^{-1}$ for the first mixture and $75+37.5 \mathrm{~g}$ a.i. ha ${ }^{-1}$ for the second one). For these rates, all spray volumes (100, 150 and $200 \mathrm{~L}$ $\mathrm{ha}^{-1}$ ) presented the same control trend, and increasing the rate had no benefit. According to the statistical analysis, reducing the fungicide rates $\left(45+52.5 \mathrm{~g}\right.$ a.i. ha $^{-1}$ trifloxystrobin + prothioconazole and $45+$ $22.5 \mathrm{~g}$ a.i. ha ${ }^{-1}$ azoxystrobin + benzovindiflupyr) resulted in decreased disease control, only superior to that of untreated plants.

Disease control varied from $37 \%$ for treatments with $100 \mathrm{~L} \mathrm{ha}^{-1}$ spray volume of $45+52.5 \mathrm{~g}$ a.i. ha $^{-1}$ trifloxystrobin + prothioconazole and $45+22.5 \mathrm{~g}$ a.i. $\mathrm{ha}^{-1}$ azoxystrobin + benzovindiflupyr, to $68.4 \%$ and $70.1 \%$ for $200 \mathrm{~L} \mathrm{ha}^{-1}$ volume of $60+70 \mathrm{~g}$ a.i. ha ${ }^{-1}$ (trifloxystrobin + prothioconazole) and $60+30 \mathrm{~g}$ a.i. ha ${ }^{-1}$ (azoxystrobin + benzovindiflupyr) or $75+87.5 \mathrm{~g}$ a.i. $\mathrm{ha}^{-1}$ and $75+37.5 \mathrm{~g}$ a.i. ha ${ }^{-1}$ for the same fungicides, respectively. According to the Brazilian legislation, one of the requirements for the registration of a pesticide is control efficacy of $80 \%$ or at least superior to that of already registered pesticides (2). Environmental conditions affect the control percentage and can reduce the fungicide performance. Fungicide application technology, such as the spray volume, can also interfere in the efficacy, as observed in the present study.
Table 2. Asian soybean rust severity, control and leaf area index (LAI), according to three fungicide rates $\left(\mathrm{g}\right.$ a.i. $\left.\mathrm{ha}^{-1}\right)$ and three spray volumes $\left(\mathrm{L} \mathrm{ha}^{-1}\right)$. Nidera 5445 soybean cultivar. Passo Fundo/RS, 2015

\begin{tabular}{|c|c|c|c|c|c|}
\hline \multicolumn{3}{|c|}{ Treatments } & \multicolumn{3}{|c|}{ Severity (\%) } \\
\hline $\begin{array}{c}\text { Spray } \\
\text { volume } \\
\left(\mathrm{L} \mathrm{ha}^{-1}\right) \\
\end{array}$ & $\begin{array}{c}\mathbf{T}+\mathbf{P}^{1} \\
\left(\mathrm{~g} \text { a.i. } \text { ha }^{-1}\right)\end{array}$ & $\begin{array}{c}\mathrm{A}+\mathbf{B}^{2} \\
\left(\mathrm{~g} \text { a.i. } \text { ha }^{-1}\right)\end{array}$ & $\begin{array}{c}60 \\
\text { DAS }\end{array}$ & $\begin{array}{c}80 \\
\text { DAS }\end{array}$ & 100 DAS \\
\hline 100 & $60+70$ & $60+30$ & $4.8 \mathrm{c}^{3}$ & $7.8 \mathrm{c}$ & $26.2 \mathrm{~d}$ \\
\hline 100 & $75+87.5$ & $75+37.5$ & $4.9 \mathrm{c}$ & $7.4 \mathrm{c}$ & $26.5 \mathrm{~d}$ \\
\hline 100 & $45+52.5$ & $45+22.5$ & $6.3 \mathrm{~b}$ & $10.1 \mathrm{~b}$ & $32.9 \mathrm{~b}$ \\
\hline 150 & $60+70$ & $60+30$ & $5.0 \mathrm{c}$ & $7.4 \mathrm{c}$ & $24.9 \mathrm{~d}$ \\
\hline 150 & $75+87.5$ & $75+37.5$ & $5.1 \mathrm{c}$ & $7.6 \mathrm{c}$ & $23.9 \mathrm{~d}$ \\
\hline 150 & $45+52.5$ & $45+22.5$ & $6.5 \mathrm{~b}$ & $10.5 \mathrm{~b}$ & $30.1 \mathrm{c}$ \\
\hline 200 & $60+70$ & $60+30$ & $4.7 \mathrm{c}$ & $7.0 \mathrm{c}$ & $16.5 \mathrm{e}$ \\
\hline 200 & $75+87.5$ & $75+37.5$ & $4,7 \mathrm{c}$ & $6.9 \mathrm{c}$ & $15.6 \mathrm{e}$ \\
\hline 200 & $45+52.5$ & $45+22.5$ & $6.0 \mathrm{~b}$ & $9.5 \mathrm{~b}$ & $30.4 \mathrm{c}$ \\
\hline Untreated & & & $10,0 \mathrm{a}$ & $17.4 \mathrm{a}$ & $52.2 \mathrm{a}$ \\
\hline \multirow[t]{2}{*}{$\mathrm{CV}(\%)$} & & & 5.98 & 5.68 & 2.03 \\
\hline & & & \multicolumn{3}{|c|}{$\begin{array}{c}\text { Control } \\
(\%) \\
\end{array}$} \\
\hline 100 & $60+70$ & $60+30$ & 52.0 & 56.8 & 49.8 \\
\hline 100 & $75+87.5$ & $75+37.5$ & 51.0 & 57.1 & 49.4 \\
\hline 100 & $45+52.5$ & $45+22.5$ & 37.0 & 35.2 & 37.0 \\
\hline 150 & $60+70$ & $60+30$ & 50.0 & 60.8 & 52.3 \\
\hline 150 & $75+87.5$ & $75+37.5$ & 49.0 & 60.4 & 54.2 \\
\hline 150 & $45+52.5$ & $45+22.5$ & 35.0 & 40.3 & 42.3 \\
\hline 200 & $60+70$ & $60+30$ & 53.0 & 63.4 & 68.4 \\
\hline 200 & $75+87.5$ & $75+37.5$ & 53.0 & 62.3 & 70.1 \\
\hline 200 & $45+52.5$ & $45+22.5$ & 40.0 & 39.6 & 41.8 \\
\hline \multirow[t]{2}{*}{ Untreated } & & & - & - & - \\
\hline & & & \multicolumn{2}{|c|}{$\begin{array}{c}\text { Leaf area index } \\
\left(\mathbf{m}^{-2} \cdot \mathbf{m}^{-2}\right)\end{array}$} & \\
\hline 100 & $60+70$ & $60+30$ & $5.79 \mathrm{a}$ & $5.59 \mathrm{a}$ & $2.62 \mathrm{a}$ \\
\hline 100 & $75+87.5$ & $75+37.5$ & $5.67 \mathrm{a}$ & $5.71 \mathrm{a}$ & $2.72 \mathrm{a}$ \\
\hline 100 & $45+52.5$ & $45+22.5$ & $4.74 \mathrm{~b}$ & $4.48 \mathrm{~b}$ & $1.97 \mathrm{~b}$ \\
\hline 150 & $60+70$ & $60+30$ & $5.52 \mathrm{a}$ & $5.31 \mathrm{a}$ & $2.54 \mathrm{a}$ \\
\hline 150 & $75+87.5$ & $75+37.5$ & $5.90 \mathrm{a}$ & $5.84 \mathrm{a}$ & $2.55 \mathrm{a}$ \\
\hline 150 & $45+52.5$ & $45+22.5$ & $4.58 \mathrm{~b}$ & $4.35 \mathrm{~b}$ & $1.92 \mathrm{~b}$ \\
\hline 200 & $60+70$ & $60+30$ & $5.51 \mathrm{a}$ & $5.70 \mathrm{a}$ & $2.87 \mathrm{a}$ \\
\hline 200 & $75+87.5$ & $75+37.5$ & $5.80 \mathrm{a}$ & $5.64 \mathrm{a}$ & $2.88 \mathrm{a}$ \\
\hline 200 & $45+52.5$ & $45+22.5$ & $4.83 \mathrm{~b}$ & $4.22 \mathrm{~b}$ & $1.99 \mathrm{~b}$ \\
\hline Untreated & & & $4.14 \mathrm{~b}$ & $4.08 \mathrm{~b}$ & $1.10 \mathrm{c}$ \\
\hline $\mathrm{CV}(\%)$ & & & 12.6 & 11.2 & 13.8 \\
\hline
\end{tabular}

${ }^{1}$ Trifloxystrobin + prothioconazole fungicides. ${ }^{2}$ Azoxystrobin + benzovindiflupyr fungicides ${ }^{3}$ Means followed by the same lowercase letter in the column do not differ according to Scott-Knott test, at $5 \%$ error probability 
Table 3. Grain yield and thousand grain mass (TGM) of soybean NS 5445 IPRO cultivar, according to three fungicide rates and three spray volumes. Passo Fundo/RS, 2015

\begin{tabular}{ccccc}
\hline $\begin{array}{c}\text { Spray } \\
\text { volume } \\
\left(\mathbf{L ~ h a ~}^{-1}\right)\end{array}$ & $\begin{array}{c}\mathbf{T}+\mathbf{P}^{\mathbf{1}} \\
\left(\mathbf{g} \mathbf{a} . \mathbf{i} . \mathbf{~ h a}^{-1}\right)\end{array}$ & $\begin{array}{c}\mathbf{A}+\mathbf{B}^{\mathbf{2}} \\
\left(\mathbf{g} \mathbf{a} . \mathbf{i} . \mathbf{h a}^{-1}\right)\end{array}$ & $\begin{array}{c}\text { Yield } \\
\left(\mathbf{k g ~ h a}^{-1}\right)\end{array}$ & $\begin{array}{c}\text { TGM } \\
\mathbf{( g )}\end{array}$ \\
\hline 100 & $60+70$ & $60+30$ & $3422 \mathrm{a}^{3}$ & $170.9 \mathrm{a}$ \\
100 & $75+87.5$ & $75+37.5$ & $3529 \mathrm{a}$ & $172.9 \mathrm{a}$ \\
100 & $45+52.5$ & $45+22.5$ & $2861 \mathrm{~b}$ & $148.1 \mathrm{~b}$ \\
150 & $60+70$ & $60+30$ & $3526 \mathrm{a}$ & $166.5 \mathrm{a}$ \\
150 & $75+87.5$ & $75+37.5$ & $3586 \mathrm{a}$ & $173.6 \mathrm{a}$ \\
150 & $45+52.5$ & $45+22.5$ & $2894 \mathrm{~b}$ & $144.5 \mathrm{~b}$ \\
200 & $60+70$ & $60+30$ & $3601 \mathrm{a}$ & $174.5 \mathrm{a}$ \\
200 & $75+87.5$ & $75+37.5$ & $3550 \mathrm{a}$ & $173.5 \mathrm{a}$ \\
200 & $45+52.5$ & $45+22.5$ & $2914 \mathrm{~b}$ & $146.3 \mathrm{~b}$ \\
\hline Untreated & - & - & $1848 \mathrm{c}$ & $120.3 \mathrm{~b}$ \\
\hline CV $(\%)$ & & & 11.5 & 9.93 \\
\hline
\end{tabular}

${ }^{1}$ Trifloxystrobin + prothioconazole fungicides. ${ }^{2}$ Azoxystrobin + benzovindiflupyr fungicides ${ }^{3}$ Means followed by the same lowercase letter in the column do not differ according to Scott-Knott test, at $5 \%$ error probability.

Leaf area index (LAI) was measured to verify the crop development, as well as defoliation that could have been caused by the rust. The mean LAI at the first general evaluation was 2.93. Maximum LAI was found between 60 and 80 DAS (Table 2). There were no statistical differences among spray volumes $\left(100,150\right.$ and $\left.200 \mathrm{~L} \mathrm{ha}^{-1}\right)$ when the rates were 60 +70 or $75+87.5$ g a.i. ha ${ }^{-1}$ for trifloxystrobin + prothioconazole and $60+30$ or $75+37.5$ g a.i. ha ${ }^{-1}$ for azoxystrobin + benzovindiflupyr, which showed the highest LAI. Reducing the fungicide rates led to inferior LAI values, similarly to those of untreated plants, at 60 and 80 DAS. Due to the crop development, the canopy tends to be thicker, which may impair the penetration of sprayed drops, especially on the lower parts of the plants. According to Butzen et al. (8), for cultivars showing larger leaves, an increase in the spray volume may provide sufficient coverage and penetration to protect soybean leaves against the pathogen. These remarks corroborate the reports by Derksen \& Sanderson (12), who observed higher coverage and lower variability in fungicide deposition along the canopy of soybean plants in response to increased application volume.

Yield and thousand grain mass showed no statistical differences among the spray volumes of 100, 150 and $200 \mathrm{~L} \mathrm{ha}^{-1}$ and the rates of $60+$ 70 or $75+87.5$ for trifloxystrobin + prothioconazole and $60+30$ or $75+$ $37.5 \mathrm{~g}$ a.i. ha ${ }^{-1}$ for azoxystrobin + benzovindiflupyr, being considered the best treatments. Treatments with reduced rates of the same fungicides $\left(45+52.5\right.$ and $45+22.5$ g a.i. ha $\left.^{-1}\right)$ and untreated plants had lower grain yield. These results evidenced the importance of using the fungicide rate recommended by the manufacturer. Trying to optimize soybean rust control, Navarini et al. (17) found that variations in the fungicide rate produced a positive effect for propiconazole, cyproconazole, and propiconazole + cyproconazole since control efficacy increased with higher fungicide rates against $P$. pachyrhizi in soybean. According to Cunha et al. $(9,10)$, the product deposition tends to increase with higher spray volumes, but no differences in grain yield were detected.

The results obtained in the experiment carried out in the laboratory corroborated with the data reported above, evidencing that the reduction in the recommended rates of trifloxystrobin + prothioconazole and azoxystrobin + benzovindiflupyr implied a directly proportional reduction in soybean rust control (Figure 1). Unsprayed leaflets showed a mean of 80.3 pustules per $\mathrm{cm}^{2}$. There was a similar cause and effect relationship for the rates of both fungicide mixtures and the number of pustules per $\mathrm{cm}^{2}$. There was a reduction of approximately 0.60 pustules $/ \mathrm{cm}^{2}$ for each $1 \%$ increase (one unit in the graph) in the rate of trifloxystrobin + prothioconazole. Using the commercial rate $(60+$ $70 \mathrm{~g}$ a.i. ha ${ }^{-1}$ ), the number of pustules $\mathrm{cm}^{-2}$ was 3.5 (95.5\% control). For azoxystrobin + benzovindiflupyr, there was a variation of 0.61 pustules $\mathrm{cm}^{-2}$ for each variation of $1 \%$ in the fungicide rate. For the commercial rate $\left(60+30 \mathrm{~g}\right.$ a.i. ha $\left.{ }^{-1}\right)$, the number of pustules $\mathrm{cm}^{-2}$ was $3.0(96.2 \%$ control) (Figure 1).

The best result for both fungicide mixtures was obtained by using their commercial rates, which presented the highest reduction percentage in the number of pustules $\mathrm{cm}^{-2}$ (Figure 1). The other rates also reduced the number of pustules $\mathrm{cm}^{-2}$ but they were not as effective as those indicated by the manufacturer. Using only half of the recommended rates of trifloxystrobin + prothioconazole $(30+35 \mathrm{~g}$ a.i. $\left.\mathrm{ha}^{-1}\right)$ and azoxystrobin + benzovindiflupyr $\left(30+15 \mathrm{~g}\right.$ a.i. ha $\left.\mathrm{h}^{-1}\right)$, disease control was reduced by $30 \%$ and $34 \%$, respectively. The results obtained under laboratory conditions simulated an ideal fungicide application on both sides of the leaflet, with no interference. In the field, a large number of factors can interfere in the fungicide coverage, including application errors, failure in the observation of the ideal weather conditions, and intrinsic characteristics of the cultivar, including leaf area index.

Tormen et al. (25) showed that fungicide coverage for the lowest leaves in the canopy of soybean plants depends on the architectural characteristics of the cultivar, including its leaf area index at application, since the leaves in the upper part of the canopy receive most spray drops and prevent the bottom leaves from receiving the same amount of the active ingredient. Cultivars that have higher leaf density and branches that are more lateral are capable of filling faster the space between the crop rows, which can impair drop penetration into the bottom part of the canopy (25). In general, there is less deposition in the bottom and inner parts of the canopy. In the case of fungicides that require uniform plant coverage, this lack of uniformity results in low disease control efficacy (9).

Antuniassi et al. (4) and Cunha et al. (9) used different spray tips to evaluate fungicide deposition and observed that there was greater coverage of the lower third of soybean canopy when tips with lower droplet spectrum were employed. Studying different pesticide application strategies, Derksen et al. (11) found that the amount of active ingredient was lower in the bottom than in the mid part of the canopy; in addition, there was less pesticide residue in the stems than in leaves at the same position in the canopy.

The fungus that cause rust tends to become more aggressive over time since they have the capability of mutating and therefore surviving under adverse conditions. According to Cunha et al. (10), only $7 \%$ of the active ingredient reaches the lower third of the soybean canopy. Considering that the surface of a soybean leaflet measures $50 \mathrm{~cm}^{2}$, both sides will be a total of $100 \mathrm{~cm}^{2}$. Thus, if $3.5 \%$ is intercepted by the adaxial side of the soybean leaflet, the droplet coverage obtained with $6+7 \mathrm{~g}$ a.i. ha ${ }^{-1}$ trifloxystrobin + prothioconazole and $6+3 \mathrm{~g}$ a.i. ha ${ }^{-1}$ azoxystrobin + benzovindiflupyr is 3.5 times greater than the expected result in the field. Therefore, the amount of fungicide that reaches the middle and the lower part of the soybean crop is very low, which is a concern since the use of low rates of demethylation inhibitors fungicide (DMIs) tends to increase the risk of sensitivity loss by the pathogen. In the same way, the fungicides quinone outside inhibitor (QoI) and succinate dehydrogenase inhibitor (SDHI) result in ineffective control in the lower part of the soybean canopy, which may require reapplication 

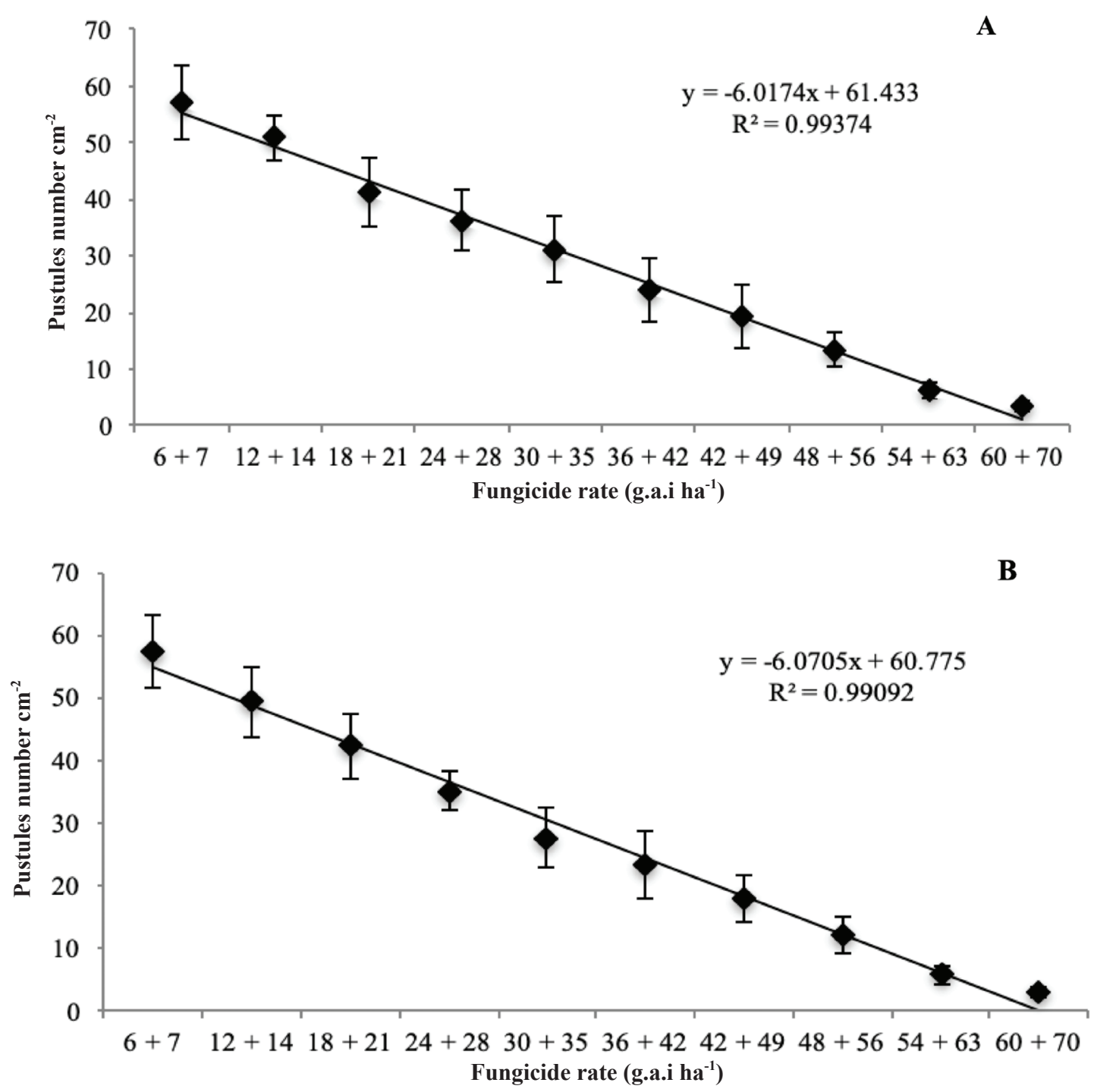

Figure 1. Linear regression for the number of Phakopsora pachyrhizi pustules in soybean leaflets as a function of the increase in the rate of fungicides trifloxystrobin + prothioconazole (a) and azoxystrobin + benzovindiflupyr (b) in the experiment carried out in a growth chamber.

of the same active ingredient in the same area more than twice during the same season, which is not recommended.

Repeated applications of sub-doses or overdoses of sitespecific fungicides, applications that are performed poorly or under inappropriate conditions such as temperature above $30^{\circ} \mathrm{C}$, air relative humidity below $55 \%$ and wind speed under $3 \mathrm{~km} \mathrm{~h}^{-1}$ or above $10 \mathrm{~km} \mathrm{~h}^{-1}$ (20) may select organisms that are resistant to the fungicide molecules used (21). Development of resistance in phytopathogenic fungi have a greater impact when using site-specific fungicides (24).

Since the efficacy of the fungicides trifloxystrobin + prothioconazole and azoxystrobin + benzovindiflupyr is directly proportional to the used rate and spray volume, improvements in the application technology are required to optimize the fungicide deposition in the target leaves in the crop and to improve ASR control.

\section{ACKNOWLEDGEMENTS}

We thank the support by the Postgraduate Program in Agronomy
(PPGAgro) of "Universidade de Passo Fundo", Rio Grande do Sul, and "Coordenação de Aperfeiçoamento de Pessoal de Nível Superior" (CAPES).

\section{REFERENCES}

1. Abbott, W.S. A method of computing the effectiveness of an insecticide. Journal Economic Entomology, Oxford, v.18, p.265-267, 1925.

2. Adapar. MAPA suspende fungicidas com baixa eficiência no controle da ferrugem-asiática da soja. Curitiba, 2017. Available at: <http://www. adapar.pr.gov.br/modules/noticias/article.php?storyid $=374>$. Acessed on: oct. 8, 2016.

3. Almeida, A.M.R.; Ferreira, L.P.; Yorinori, J.T.; Silva, J.F.V.; Henning, A.A.; Godoy, C.V.; Costamilan, L.M.; Meyer, M.C. Doenças da soja. In: Kimati, H.; Amorim, L.; Rezende, J.A.M.; Bergamin Filho, A.; Camargo, L.E.A. (Ed.). Manual de fitopatologia. São Paulo: Agronômica Ceres, 2011. pp. 569-588.

4. Antuniassi, U.R.; Camargo, T.V.; Bonelli, M.A.P.O.; Romagnole, E.W.C. Avaliação da cobertura de folhas de soja em aplicações terrestres com diferentes tipos de pontas. In: III Simpósio Internacional de Tecnologia de Aplicação de Agrotóxicos, n. 3, 2004, Botucatu. Anais. Botucatu: Fepaf, 2004. p.48-51. 
5. Azevedo, L.A.S. Qualidade da aplicação de fungicidas protetores. In: Azevedo, L.A.S. Fungicidas protetores: fundamentos para o uso racional. Campinas: Camopi, 2003. p.121-132.

6. Blum, M.M.C. Sensibilidade de Phakopsora pachyrhizi a fungicidas. 2009. 173f. Thesis (Ph.D. in Phytopathology) - Faculdade de Agronomia e Medicina Veterinária, Universidade de Passo Fundo, Passo Fundo.

7. Buzzerio, N.F.; Basso, M.E.; Lachi, G.B.; Lovato, B.V.; Gonçalves, F.A.; Paiva, S.B. Determinação de metodologia para produção de inóculo de Phakopsora pachyrhizi em condições de laboratório para fins de estudos de sensibilidade. Summa Phytopathologica, Botucatu, v.33, p.61, 2007.

8. Butzen, S.; Marcon, A.; Mcinnes, B.; Schuh, W. Asian soybean rust: fungicide application technology. Crop Insights, Johnston, v.15, p.1-6, 2005.

9. Cunha, J.P.A.R.; Reis, E.F.; Santos, R.O. Controle químico da ferrugem asiática da soja em função de ponta de pulverização e volume de calda. Ciência Rural, Santa Maria, v.36, p.1360-1366, 2006.

10. Cunha, J.P.A.R.; Moura, E.A.C.; Silva, J.L.J.; Zago, F.A.; Juliatti, F.C. Efeito de pontas de pulverização no controle químico da ferrugem da soja. Engenharia Agrícola, Jaboticabal, v.28, p.283-291, 2008.

11. Derksen, R.C.; Sanderson, J.P. Volume, speed and distribution technique effects on poinsentia foliar deposits. Transactions of the ASABE, St. Joseph, v.39, p.5-9, 1996.

12. Embrapa Trigo. Agrometeorologia. Passo Fundo, 2016. Available at: $<$ http://www.cnpt.embrapa.br/pesquisa/agromet/app/principal/agromet. php>. Acessed on: May 12, 2016.

13. Embrapa Trigo. Clima de Passo Fundo. Passo Fundo, 2016. Avalilable at: $<$ http://www.cnpt.embrapa.br/pesquisa/agromet/pdf/Clima_de_Passo_Fundo.pdf $>$. Acessed on: May 12, 2016.

14. Fungicide Resistance Action Committee (FRAC). Methods for monitoring fungicides resistance. EPPO Bulletin, West Sussex, v.21, p.291-354, 1991.

15. Godoy, C.V.; Koga, L.J.; Canteri, M.G. Escala diagramática para avaliação da severidade da ferrugem da soja. Fitopatologia Brasileira, Brasília, DF, v.31, p.63-68, 2006.

16. Scherb, C.T; Mehl, A.;. Detached leaf test method. Fungicide Resistance Action Committee, 2006. Available at: <http://www.frac.info/ docs/default-source/monitoring-methods/approvedmethods/phakpa-detached-leaf-monitoring-method-bcs-2006v1.pdf?sfvrsn=4e9a419a_4>. Acessed on: May 12, 2016

17. Navarini, L.; Dallagnol, L.J.; Balardin, R.S.; Moreira, M.T.; Meneghetti, R.C.; Madalosso, M.G. Controle químico da ferrugem asiática (Phakopsora pachyrhyzi Sidow) na cultura da soja. Summa Phytopathologica, Botucatu, v.33, p.182-186, 2007.

18. Oliveira, A.C.B.; Rosa, A.P.S.A. Indicações técnicas para a cultura da soja no Rio Grande do Sul e Santa Catarina, safras 2014/2015 e 2015/2016. Pelotas: Embrapa Clima Temperado, 2014.

19. Reis, E.M.; Reis, A.C.; Carmona, M.A. Fungitoxidade e sensibilidade. In: Reis, E.M.; Reis, A.C.; Carmona, M.A. Manual de fungicidas: guia para o controle químico de doenças de plantas. Passo Fundo: Universidade de Passo Fundo, 2010. p.26-29.

20. Reunião de Pesquisa de Soja da Região Sul. Indicações técnicas para a cultura da soja no Rio Grande do Sul e em Santa Catarina, safras 2012/2013 e 2013/2014. Passo Fundo: Embrapa Trigo, 2012. 142p.

21. Roese, A.D. O melhor fungicida contra a ferrugem asiática da soja. Infobibos, 2011. Available at: < http://infobibos.com/Artigos/2011_1/fungicida/index. htm>. Acessed on: July 10, 2016.

22. Santos, J.A.; Juliatti, F.C.; Santos, V.A.; Polizel, A.C.; Hamawaki, O.T. Caracteres epidemiológicos e uso da análise de agrupamento para resistência parcial à ferrugem da soja. Pesquisa Agropecuária Brasileira, Brasília, DF, v.42, p.443-447, 2007.

23. Sauer, R. Fungizide brauchen "ziehlwasser". DLL-Agrarmagazin, München, v.2, p.76-77, 1999.

24. Sierotzki, H.; Scalliet, G.A. Review of Current Knowledge of Resistance Aspects for the Next-Generation Succinate Dehydrogenase Inhibitor Fungicides. Phytopathology, St. Paul, v.103, n.9, 2013.

25. Tormen N.R.; Silva, F.D.L.; Debortoli, M.P.; Uebel, J.D.; Dalla Fávera, D.; Balardin, R.S. Deposição de gotas no dossel e controle químico de Phakopsora pachyrhizi na soja. Revista Brasileira de Engenharia Agrícola e Ambiental, Campina Grande, v.16, p.802-808, 2012. 